\title{
Meanings attributed by family members in pediatrics regarding their interactions with nursing professionals*
}

\author{
Significados atribuídos por familiares na pediatria acerca de suas \\ interações com os profissionais da enfermagem \\ Significados atribuidos por familiares en la pediatría acerca de sus \\ interacciones con los profesionales de la enfermería
}

Giovana Calcagno Gomes ${ }^{1}$, Daiani Modernel Xavier ${ }^{2}$, Aline Campelo Pintanel${ }^{1}$, Dóris Helena Ribeiro Farias ${ }^{1}$ Valéria Lerch Lunardi $^{1}$, Deise Ribeiro Aquino ${ }^{1}$

\footnotetext{
* Extracted from the dissertation"Percepção de familiares acerca do cuidado de enfermagem prestado na Unidade de Pediatria”, Programa de Pós-Graduação em Enfermagem, Escola de Enfermagem, Universidade Federal do Rio Grande, 2013.

${ }^{1}$ Universidade Federal do Rio Grande, Rio Grande, RS, Brazil.

${ }^{2}$ Universidade Federal do Rio Grande, Programa de Pós-Graduação em Enfermagem, Rio Grande, RS, Brazil.
}

\section{ABSTRACT}

Objective: Understanding the meanings attributed by family caregivers of children in hospital environments about their interactions with nursing professionals. Methods: This qualitative study used Symbolic Interactionism as a theoretical reference and Grounded Theory as the methodological framework. It was carried out in a Pediatrics Center in southern Brazil, in the first half of 2013. Participants were 15 family caregivers of hospitalized children. Data were collected through interviews and submitted to open and axial analysis. Results: Interactions with the nursing team enable family to trust or distrust in the provided child care and to positively evaluate the care received. Conclusion: Interactions between family members and the nursing team contribute to the significance attributed by the family to the nursing care received by the child. Nurses should be aware of the attitudes of the nursing team regarding the child and their family, prioritizing humanized care.

\section{DESCRIPTORS}

Child, Hospitalized; Family; Professional-Family Relations; Pediatric Nursing.
Corresponding author:

Daiani Modernel Xavier

General Osório, $\mathrm{s} / \mathrm{n}^{\circ}$ - Campus da Saúde

CEP 96201-900 - Rio Grande, RS, Brazil

daiamoder@ibest.com.br 


\section{INTRODUCTION}

The need for hospitalizing children usually presents itself as a time of hardship and vulnerability for both the child and their family, and one that needs help to adapt to the experienced situation ${ }^{(1-2)}$. The hospitalization of a child into the hospital can constitute a potentially traumatic experience and it may be experienced with fear and insecurity.

Since this is an unknown and commonly feared context, the family caregiver intensifies their attention on the care provided to the child by being attentive to the care provided by the nursing team to the child during their hospital stay, recognizing it as being appropriate or not ${ }^{(3)}$. From that recognition, they decide to trust or not trust in the nursing professional team ${ }^{(4)}$. Knowledge is processed through interactions between the subject and the environment. Thus, the social role of the subjects in an interaction presents itself as fundamental for the knowledge building process ${ }^{(5)}$.

Hospitalized children present vulnerabilities, requiring specialized care ${ }^{(6)}$. The care can be understood as a set of procedures performed by health/nursing professionals for the successful treatment of the child, but also requires assistance/care from their family, and therefore it should be shared $^{(7)}$. Child care requires not only technical expertise, but also global action involving both family caregivers and nursing team professionals. It involves treating, respecting, accepting, understanding and serving them in their needs, minimizing their suffering through humanized and comprehensive care ${ }^{(8)}$.

In this context, family caregivers seek to contribute to child care, trying to ensure the quality of the nursing care provided $^{(1)}$. This care is intended for the children's well-being and recovery, and also reaches their families who accompany this process through human interactions with nursing professionals ${ }^{(3-4)}$. It is through this interaction process that humans comprehend the world they live in. Social interaction is essential for the process of coexisting among people, interfering with their attitudes and behaviors that influence the values and meanings that people have about life in community. From this perspective, human behavior is formed by the person in the course of action ${ }^{(5)}$.

Therefore, the family can evaluate child nursing care as positive when nursing professionals show concern in developing differentiated care for children, treating them with care, interacting with them throughout their hospitalization process $s^{(4)}$, sharing with the family caregiver information needed in caring for children in the hospital and/or clarifying their doubts ${ }^{(3-4)}$.

The recognition of good care provided to the family and children is related to the quality of the information provided by the nursing team professionals ${ }^{(3-4)}$ that assist the child and become part of their social support network in the hospital. Nurses can provide information and assistance to exploit the family in the hospital, so that they may become an effective source of help and support, empowering them as caregivers. For this, clear and open dialogue between the health team and the family is crucial in order to mitigate doubts, fears and insecurities common in the hospital setting ${ }^{(8)}$. However, the interaction process may present inconsistent expectations and behaviors between professionals and family, generating feelings of helplessness ${ }^{(9)}$.

In Symbolic Interaction (SI), social interactions are vital in the process of conviviality being intertwined in the attitudes, human behavior, values and meanings that people have about life in community. The symbolic interaction mediates the process of forming individual behavior and conduct, as well as collective human behaviors coexisting in social groups ${ }^{(5)}$.

In this coexistence, nursing teams make themselves available, facilitating the establishment of ties to family caregivers and hospitalized children, and understanding the context in which they are inserted, thereby being able to establish reciprocity of care. The shared care between the nursing team and the family caregiver can contribute to improving the care and treatment of children in hospitals ${ }^{(3-4)}$.

During the child's hospital stay, there is a physical and emotional closeness between the child, the family caregiver and the nursing team professionals. From this proximity, family members can visualize the nursing care being offered $^{(4)}$. It is believed that understanding family perception of the care the nursing team provides to the child at the hospital enables these professionals to better themselves in order to provide comprehensive care adherent to the real needs of hospitalized children.

So the question that guided this study was: What is the meaning attributed by family caregivers of children in hospital environments about their interactions with professionals of the nursing team? From there, the study aimed to understand the meanings attributed by family caregivers of children in hospital environments about their interactions with the nursing team professionals.

\section{METHOD}

This is an exploratory descriptive research of a qualitative approach that used Grounded Theory (GT) as a methodological reference. This methodology consists of collecting, coding, and simultaneous and systematic data comparisons, enabling exploration of the investigated phenomenon, generating a theory that can explain and facilitate understanding of social and cultural phenomena. GT can generate theories by describing and interpreting phenomena, allowing for in-depth knowledge of the multidimensional experience of human beings in their daily lives ${ }^{(10)}$.

The research was developed in the Pediatric Unit of a hospital in southern Brazil, which has 21 beds all reserved for children attended by the Unified Health System (SUS). 15 family caregivers of hospitalized children participated in the study between November and December 2013 (the period of data collection). They were selected according to the following inclusion criteria: being the main caregiver of the child and providing direct care at the hospital. Any occasional caregivers of the children were excluded.

The number of participants and their sample groups were configured as data were collected and analyzed by the theoretical sampling process, as recommended by GT. Participants were divided into four sample groups: two formed by 
five family members, one formed by three and the other by two members. They were interviewed in four different shifts (morning, afternoon, night 1 and night 2), respectively. It was considered that the number of participants per sample group ensured theoretical saturation of the data content. Theoretical saturation can be considered when categories start to repeat themselves and new data are not achieved ${ }^{(10)}$.

The first sample group consisted of family caregivers who highlighted the positive aspects of nursing care from the professionals interacting with the child and the family caregiver. The second sample group had the participation of family members who showed a better understanding of the confidence generated from the interactions with the nursing staff, and the third group mentioned aspects of mistrust generated from the interactions with the nursing team. The fourth sample group was used to validate the data submitted by participants from previous groups. Thus, the study involved a total of 15 participants. This number of participants became enough as soon as statements did not bring any new information relevant to the research, characterizing the theoretical saturation of data.

Data collection was conducted through semi-structured interviews, unique to each caregiver, focusing on the hospitalized child's family caregivers perceptions about their interactions with nursing team professionals, and carried out in the unit's hospital room. Their average duration was 30 minutes, and they were scheduled with each family, recorded and transcribed for analysis. Substantive analysis was carried out through open data coding, which was line by line data examination, separating units of analysis and axial coding with their categorization from the data ${ }^{(10)}$. The category presented in this study was to assign meanings to the interaction with the nursing team professionals. Selective analysis of the complete database was not presented in this study.

The project was approved by the Research Ethics Committee (CEPAS/FURG) under Protocol 21/2013 and Certificate of Presentation of Ethics Consideration number 11507312.1.0000.5324, fulfilling the requirements of the National Health Council resolution 466/12, on standards and regulatory guidelines for research involving human beings ${ }^{(11)}$. Participants signed the Informed Consent Form. They were identified by the letter $\mathrm{F}$ followed by an interview number.

\section{RESULTS}

Data analysis revealed three categories: Interacting with the child and the family caregiver and receiving a positive care assessment; Interacting with the nursing staff and trusting the care received by the child; Interacting with the nursing staff and distrusting the provided care.

\section{INTERACTING WITH THE CHILD AND THE FAMILY CAREGIVER AND RECEIVING A POSITIVE CARE ASSESSMENT}

The family caregiver recognizes the care provided by the nursing team professionals as effective when professionals are attentive and available, meeting their demands on time and in a manner they consider correct.
Here, everyone is very attentive. I have nothing to complain about. The nurses and assistants are very good. They are very thoughtful, always very loving when you come back (F1).

Everyone is great, everything (happens) at the right time, everything is right. The child gets better soon, because of all their attention (F3).

The professionals are always available, always around to assist us in care. I value that. (...) There is no delay in care. I am always informed of the schedules and everything, so I think we're very well treated here (F5).

In the opinion of the caregivers, care is seen as positive when they perceive that the staff cares about the child and their family caregivers.

\section{I think the nurses and the assistants are very in- terested. I acknowledge the attention given to me by all of the staff $(\mathrm{F} 2)$. \\ I see their concern with child care and even with us. (F4).}

For the routine of families in the hospital, nursing care is recognized as appropriate when they perceive development and improvement of the child's clinical condition and consider the provided care was consistent with the child's needs.

I think that the care provided in the hospital is good. I have nothing to complain about. (...) I see that she is well cared for and well treated. She is getting everything she needs (F6).

I think the nurses are very good and thoughtful. They are careful, nice. I have nothing to complain about them. They are dedicated to the children here (F7).

I'm glad to see my son being treated well. It makes me feel peaceful (F9).

During their interaction with nursing team professionals, they consider child care satisfying when they recognize that professionals are attentive to the work they do and have the proper knowledge about the work they do.

I see that they really know what they are doing. They bave great knowledge about child care (F10).

They know what they are doing and they are very thoughtful with the children. They are always very attentive. They have training and experience. I feel safe with the service (F12).

In the opinion/view of family caregivers, care is recognized as good when the nursing team professionals teach the family to care for the child in the hospital, providing tools/knowledge, thus empowering them as the caregivers.

I see nurses teaching mothers how to provide care because some children need different care than at home. Mothers need to learn the process with the 
saline, the drains. It is difficult and it would be even more difficult without help (F11).

\section{INTERACTING WITH THE NURSING STAFF AND TRUSTING CARE RECEIVED BY THE CHILD}

During interactions with nursing professionals, from the moment family members recognize the provided child care as appropriate, they begin to trust the professionals providing the service. By trusting the care received by the child, the family members become calmer, thus contributing to building a positive partnership with the nursing team.

I trust them because I am always asking them questions. When we know what is happening, we are better equipped to evaluate and see if everything is fine. From there comes the trust, because nothing is hidden. It's all in the open, everything well spoken, evaluated, controlled (F14).

What makes us trust in the work of professionals is seeing our children's needs well met. I'm sure he is getting the care he needs (F4).

When the family trusts the members of the nursing staff, they transfer part of the responsibility for child care and interfere less. Trusting the care provided gives security and tranquility to the family, and they can then have a less traumatizing hospitalization experience.

I trust that they know what they are doing. I try not to interfere with the treatment and examinations, medication and diet. I really do trust them (F13).

I leave everything to the account of the team. I trust in them, in their decisions (F15).

Trust in professional care comes from the certainty of availability for care; the security of information received from professionals; the interest and commitment of these professionals with the care they provide and the fact of being heard and having their concerns taken into account by professionals.

\section{I have peace of mind to sleep because I'm calm, because I trust the care received. Everything is done on time. They show interest in the child. We notice their commitment with them, with their work, with the care, the children. (F6).}

I trust the information I receive and I consider the treatment appropriate. I trust the team decisions and the professionals. I have confidence in the nurses' knowledge because they make me aware of everything (F9).

They answer my questions and I feel safe with the information received ( $\mathrm{F} 11)$.

\section{INTERACTING WITH THE NURSING STAFF AND DISTRUSTING PROVIDED CARE}

When the family remains uninformed about the child's treatment, despite their interactions with nursing professionals and feel they do not have control over the situation, they may become unsure about the care received by the children.
Nobody tells me anything here. They don't talk to us properly. I do not like it. I want to know ev- erything about my daughter and they don't talk to us. I think she had to do some tests, (...) We are completely unaware of what is happening. Even though I'm alert, I feel insecure (F15).

The families realize that professionals are unprepared to take care of their complaints, often disregarding the subjectivity contained in the hospitalization process and the suffering it causes to family caregivers of children. This distant and superficial relationship can generate distrust in the family about the quality of care being given.

\section{I know that professionals have their own person- al problems. (...) But sometimes, we need atten- tion, a word and some of them are very distant. They walk in and out without even talking to us. How can we trust them, then? (F10). \\ (...) They say a few words and think it is enough, that they did us a great favor. They are cold, im- personal (F13).}

A lack of sensible listening generates feelings of distrust and helplessness. These feelings arise from not being heard by professionals; not receiving sufficient explanations about the child's treatment, and from not having their views taken into consideration by the professionals who care for them.

They do not listen to us and do not accept our mother's opinion. They think that because they studied they know everything. They give us pieces of information and think we understand everything (F2).

Just yesterday I saw the neurologist. The nurse came in telling me that no, the neurologist was in Porto Alegre. (...). I ran into the doctor downstairs (...). I completely lost it yesterday. They lied to me (F14).

Family members distrust in the care received by the child when they believe that the number of professionals providing care is insufficient, which makes the service unavailable sometimes.

Yesterday I was desperate. Not because he was having a crisis, but because of the delay. I called the doctor, the nursing staff. But it takes too long, it is irritating. I know they don't have enough and there are a lot of children, but it was an emergency. This is absurd! (F6).

The number of nurses is insufficient. The manpower is not enough and it makes me nervous, because I have to be a thousand times more aware because my child has a fever and diarrhea. It is not that I distrust them, but I do not feel safe (F1). 


\section{DISCUSSION}

In Symbolic Interaction (SI), the human being is seen as a social body that engages in interaction with themselves, by making statements to themselves and answering these indications. Because of this engaging interaction, the human being is placed in a different situation with their environment, as an active organism. For SI, the human being is an actor in the world by defining the world in which they act, based on conscious choices ${ }^{(12)}$.

The meaning attributed to each situation experienced by the family regarding the care of their hospitalized children interferes in their evaluation of the received nursing care ${ }^{(13)}$. The interaction of nursing professionals with families in the hospital is reflected in helpful relationships. The family is able to assess the care provided by this interaction ${ }^{(8)}$. The hospital is revealed as an environment where professional care that focuses on the biological and symbolic physicality of being a child and being a family that experiences the hospitalization. The nursing staff expresses the significance attached to human life and to their work through their care. This meaning is manifested in the course of care actions and care that is recognized by the family who is evaluating them ${ }^{(13)}$.

By interacting with professionals of the nursing team, the family can evaluate their care as positive. Qualified care is associated with greater satisfaction. Consequently, attentive and available professionals who are skillful communicators and are concerned about the child and the family caregivers have their care considered as satisfactory ${ }^{(1)}$. A positive correlation of satisfaction with care involves nurses considering emotional aspects in their clinical practice, spending more time with their patients and paying attention to patient demands ${ }^{(3)}$.

Caregivers consider nursing care positive when they notice the evolution and improvement of the child's clinical condition $^{(1)}$. In addition, there seems to be a direct relationship between mothers' satisfaction with the care received when these are compatible with the child's needs. A study has shown that mothers have greater satisfaction with the received care when they recognize that professionals are attentive to the work they do ${ }^{(14)}$.

By interacting with professionals, family caregivers may feel satisfied with the care when they recognize that they (the professionals) have the knowledge about the work they do, meeting the needs of the children, promoting their welfare and recovery ${ }^{(15)}$. Care is considered positive when nursing staff professionals teach the family how to care for the child in the hospital, providing them with tools/knowledge and empowering them as caregivers. Nurses' interaction with the child's family allows their caring action to be founded on respect and strengthening of ties. Establishing a close relationship, assessing and meeting their educational needs can generate satisfaction and reflect in appropriate and effective care ${ }^{(16)}$.

When interacting with the nursing staff, the family can trust the care received by the child. They express confidence in the professional care when the child care is extended to them, when they are heard and their demands are met, when they recognize that their interactions with the team are positive and they feel part of the daily life of these professionals, sharing the child care with them ${ }^{(13,17)}$.

Families need to get to know and trust the professionals so that their partnership is positive ${ }^{(9)}$. They trust the provided care when they identify that the nurses have an empathetic relationship with them, recognizing that professionals seem to put themselves in their place, realizing what they feel and think, and the significance of this experience for the family. The shared practice is one in which the family realizes staff availability for the care, improvement of the child's clinical condition and their concern for the children and their families ${ }^{(17)}$.

By trusting the care received by the child, they become more relaxed, contributing to building a positive partnership with the nursing team professionals ${ }^{(3)}$. Confidence in care gives the family security and tranquility to experience a less traumatic hospitalization of the child. Confidence in professional care comes from certainty of the availability for care and the security of information received from professionals. Factors such as effective nurse-patient communication, mutual respect, interests and commitment of professionals for the care they provide and attentive listening significantly contribute to parental satisfaction with the care provided to hospitalized children ${ }^{(18)}$.

In contrast, when the family considers that their interactions with professionals are negative, they may recognize the care received as inadequate. A study aimed at investigating the impact of nursing characteristics in care settings found that the presence or absence of trust, respect, equality of status and the professionals' availability of time are critical and must occur prior to the implementation of any other strategy to improve communication between professionals and service users ${ }^{(19)}$. Human beings act based on their observations, interpretations and establishments in a process called interpretative interaction ${ }^{(5)}$.

The development of trust requires consistent interaction. Thus, impersonal relationships in which professionals create fewer opportunities for interaction may be generating mistrust in families on the quality of care provided by workers to the child. They may distrust the care provided when they have no control over the situation they are in, when they are not involved in child care planning and are kept uninformed about the child's treatment ${ }^{(20)}$.

They are suspicious about the care provided if they believe that professionals are poorly prepared or that the number of professionals providing care in the sector is insufficient $t^{(1)}$. In a study about the dimension of child nursing care in the hospital, it was found that nursing is based on procedures, that the interaction with children and family is tangential in the care process, and that despite the family sharing the care with the nursing staff, they are not included in the care perspective ${ }^{(21)}$. This situation only contributes to the gap between what is recommended and valued as part of the nursing profession and proper for nursing professionals, causing the family to not be heard during the child's hospitalization process, contributing to their distrust in the provided care. 


\section{CONCLUSION}

The data obtained in this study enables understanding of the meanings attributed by family caregivers of children in the hospital environment about their interactions with the professional nursing team. From this study, it becomes clear that child hospitalization generates concern and anxiety for the family. The interaction established between nursing professionals and the child/family facilitates the provision of nursing care and can lessen the trauma generated by hospitalization. Social interactions are vital in the process of interaction between professionals and families, interfering in attitudes and family behaviors, influencing their meaning attributed to care.

As implications for practices considered necessary to increase the family's confidence in the nursing team professionals, the professionals should demonstrate availability for attentive listening, develop educational actions with a view to exploit and empower the family to care for the child. It is necessary to develop a communicative relationship with caregivers, keeping them informed and engaged throughout the child's hospitalization process. A commitment coupled with professional skills can build trust with the family when they see actions taken, and can reproduce them. This causes them to be involved in the process and part of the care offered, making the family active protagonists in child care.

It was concluded that the interactions between the family and the nursing staff contribute to the significance attributed by the family caregiver to their child's nursing care actions. Nurses should pay attention to the nursing team's attitudes in front of the child and family caregivers in the hospital, prioritizing humanized care. Thus, nursing care can be positively evaluated by family caregivers because it meets their needs, helping them to overcome their sources of anxiety and stress.

Training and qualification for care of children in hospitals and building positive interactions with them and their families become necessary to establish assistance, enabling adoption of effective care/treatment standards, generating confidence in the family caregiver, enabling transformation of professional practice, and thus avoiding disintegration of care.

The limitation of this study can be considered in its unique context. Therefore, replicating the study in other realities or new exploration about the interactions between families and professionals may ultimately give greater visibility of their importance.

\section{RESUMO}

Objetivo: Compreender os significados atribuídos por familiares cuidadores da criança no ambiente hospitalar acerca de suas interações com os profissionais da equipe de enfermagem. Método: Estudo qualitativo que utilizou o Interacionismo Simbólico como referencial teórico e a Grounded Theory como metodológico. Foi realizado em uma Pediatria no sul do Brasil, no primeiro semestre de 2013. Participaram 15 familiares cuidadores de crianças internadas. Os dados foram coletados por entrevistas e submetidos à análise aberta e axial. Resultados: As interações com a equipe de enfermagem possibilitam à família confiar ou desconfiar do cuidado prestado à criança e avaliar positivamente o cuidado recebido. Conclusão: As interações entre familiares e equipe de enfermagem contribuem para a significação atribuída pelo familiar ao cuidado de enfermagem recebido pela criança. Cabe ao enfermeiro atentar para as atitudes da equipe de enfermagem frente à criança e seu familiar, priorizando o cuidado humanizado.

\section{DESCRITORES}

Criança Hospitalizada; Família; Relações Profissional-Família; Enfermagem Pediátrica.

\section{RESUMEN}

Objetivo: Comprender los significados atribuidos por familiares cuidadores del niño en el entorno hospitalario acerca de sus interacciones con los profesionales del equipo de enfermería. Método: Estudio cualitativo que utilizó el Interaccionismo Simbólico como marco de referencia teórico y la Grounded Theory como metodológico. Fue realizado en una Pediatría del sur de Brasil, el primer semestre de 2013. Participaron 15 familiares cuidadores de niños ingresados. Los datos fueron recogidos por entrevistas y sometidos al análisis abierto y axial. Resultados: Las interacciones con el equipo de enfermería posibilitaron a la familia confiar o desconfiar del cuidado prestado al niño y valorar positivamente el cuidado recibido. Conclusión: Las interacciones entre familiares y equipo de enfermería contribuyen a la significación atribuida por el familiar al cuidado de enfermería recibido por el niño. Le toca al enfermero fijarse en las actitudes del equipo de enfermería ante un niño y su familiar, priorizando el cuidado humanizado.

\section{DESCRIPTORES}

Niño Hospitalizado; Familia; Relaciones Profesional-Familia; Enfermería Pediátrica

\section{REFERENCES}

1. Hosseinian M, Mirbagher Ajorpaz N, Esalat Manesh S. Mothers' satisfaction with two systems of providing care to their hospitalized children. Iran Red Crescent Med J [Internet]. 2015[cited 2015 Apr 13];17(2):e23333. Available from: http://www.ncbi.nlm.nih.gov/pmc/ articles/PMC4376982/

2. Oliveira K, Veronez M, Higarashi IH, Corrêa DAM. Vivências de familiares no processo de nascimento e internação de seus filhos em UTI neonatal. Esc Anna Nery Rev Enferm [Internet]. 2013 [citado 2014 fev. 26];17(1):46-53. Disponível em: http://www.scielo.br/pdf/ ean/v17n1/07.pdf

3. Ziviani J, Darlington Y, Feeney R, Rodger S, Watter P. Early intervention services of children with physical disabilities: complexity of child and family needs. Aust Occup Ther J. 2014;61(2):67-75. 
4. Salehi Z, Mokhtari Nouri J, Khademolhoseini M, Ebadi A. Survey of parents Satisfaction of infants admitted in the NICU. Iran J Crit Care Nurs. 2015;7(4):245-52.

5. Blumer H. Symbolic interactionism: perspective and method. Berkeley: University of California Press; 1969.

6. Oliveira LN, Breigeiron MK, Hallmann S, Witkowski MC. Vulnerabilities of children admitted to a pediatric inpatient care unit. Rev Paul Pediatr. 2014;32(4):367-73.

7. Furtado MCC, Silva LCT, Mello DFM, Lima RAG, Petri MD, Rosário MM. Uma integralidade da assistência à criança na percepção fazer aluno de graduação em Enfermagem. Rev Bras Enferm [Internet]. 2012 [citado 2015abr. 13];65(1):56-64. Disponível em: http://www. scielo.br/pdf/reben/v65n1/08.pdf

8. Gomes GC, Leite FLLM, Souza NZ, Xavier DM, Cunha JC, Pasini D. Estratégias utilizadas pela família para cuidar a criança no hospital. Rev Eletr Enf [Internet]. 2014 ;[citado 2015 jul. 01];16(2):434-42. Disponível em: https://www.fen.ufg.br/fen_revista/v16/n2/pdf/v16n2a21.pdf

9. Baltor MRR, Matos APK, Wernet M, Ferreira NMLA, Dupas G. The perceptions of families with children having chronic diseases and their relationships with healthcare professionals. Rev Esc Enferm USP [Internet]. 2013 [cited 2014 Nov 8];47(4):808-14. Available from: http:// www.scielo.br/pdf/reeusp/v47n4/en_0080-6234-reeusp-47-4-0808.pdf

10. Strauss A, Corbin J. Pesquisa qualitativa: técnicas e procedimentos para o desenvolvimento da teoria fundamentada. Porto Alegre: Artmed; 2008.

11. Brasil. Ministério da Saúde; Conselho Nacional de Saúde. Resolução n. 466, de 12 de dezembro de 2012. Dispõe sobre diretrizes e normas regulamentadoras de pesquisas envolvendo seres humanos [Internet]. Brasília; 2012 [citado 2014 out. 02]. Disponível em: http://conselho. saude.gov.br/resolucoes/2012/Reso466.pdf

12. Charon JM. Symbolic Interactionism: an introduction, aninterpretation, an integration. $3^{\text {a }}$ ed. Englewood Cliffs: Prentice Hall; 1989.

13. Valizadeh L, Zamanzadeh V, Akbarbegloo M, Sayadi L. Importance and availability of nursing support for mothers in NICU: a comparison of opinions of Iranian mothers and nurses. Iran J Pediatr [Internet]. 2012 [cited 2015Apr 13];22(2):191-6. Available from: http://www.ncbi. nlm.nih.gov/pmc/articles/PMC3446074/pdf/IJPD-22-191.pdf

14. Kamimura A, Ashby J, Myers K, Nourian MM, Christensen N. Satisfaction with healthcare services among free clinic patients. J Community Health. 2015;40(1):62-72.

15. Schoenfelder T, Schaal T, Klewer J, Kugler J. Patient satisfaction and willingness to return to the provider among women undergoing gynecological surgery. Arch Gynecol Obstet. 2014;290(4):683-90.

16. Pype P, Wens J, Stes A, Grypdonck M, Eynden BV, Deveugele M. Patients' nursing records revealing opportunities for interprofessional workplace learning in primary care: a chart review study. Educ Health (Abingdon). 2014;27(1):89-92.

17. Bastani F, Abadi TA, Haghani $\mathrm{H}$. Effect of family-centered care on improving parental satisfaction and reducing readmission among premature infants: a randomized controlled trial. j Clin Diagn Res [Internet]. 2015 [cited 2015 Apr 11];9(1):SC04-8. Available from: http:// www.ncbi.nlm.nih.gov/pmc/articles/PMC4347142/

18. Kourkouta L, Papathanasiou IV. Communication in nursing practice. Mater Socio Med [Internet]. 2014 [cited 2015 July 01];26(1):65-7. Available from: http://www.ncbi.nlm.nih.gov/pmc/articles/PMC3990376/

19. Carmona EV, Coca KP, Vale IN, Abrão ACFV. Mother role conflicts in studies with mothers of hospitalized newborns: an integrative review. Rev Esc Enferm USP [Internet]. 2012 [cited 2015 Apr 11];46(2):505-12. http://dx.doi.org/10.1590/S0080-62342012000200032

20. Martins PAF, Alvim NAT. Plano de cuidados compartilhado: convergência da proposta educativa problematizadora com a teoria do cuidado cultural de enfermagem. Rev Bras Enferm [Internet]. 2012 [citado 2015 abr. 5];65(2):368-73. Disponível em: http://www.scielo.br/pdf/ reben/v65n2/v65n2a25.pdf

21. Docherty SL, Thaxton C, Allison C, Barfield RC, Tamburro RF. The nursing dimension of providing palliative care to children and adolescents with cancer. Clin Med Insights Pediatr [Internet] 2012 [cited 2015 Apr 10];6:75-88. Available from: http://www.ncbi.nlm.nih.gov/pmc/ articles/PMC3620813/ 